\title{
The Impact of Conflicts in Foreign Business Relationships on SME Performance
}

\author{
Milena Ratajczak-Mrozek, Krzysztof Fonfara, Aleksandra Hauke-Lopes
}

\section{A B S T R A C T}

Objective: The objective of the article is to discuss the impact of conflicts in foreign business relationships on the performance of SMEs. Two possible ways in which conflicts influence the company's performance are considered: direct (conflicts $\rightarrow$ company's performance) and indirect (conflicts $\rightarrow$ business relationships $\rightarrow$ company's performance).

Research Design \& Methods: The article uses the case study method and presents the results of a study of 13 SMEs operating in international markets.

Findings: The article proposes a model of the positive impact of conflicts in foreign business relationships on SME performance. A model links relational and operational sources of conflicts with their direct and indirect (through relationships) impact on SME performance and positive and negative outcomes.

Implications \& Recommendations: The article provides information how to transform conflicts in foreign business relationships into positive outcomes. A crucial role in this respect is played by moderators: trust and informal relationship development, cultural awareness and formal action development.

Contribution \& Value Added: The originality of the study is that it identifies the main operational and relational sources of conflict situations that impact (directly and indirectly) SMEs performance in their international activities. The identified 4 moderators, by positively impacting SMEs foreign relationship in conflict situations, help these companies to obtain positive conflict outcomes.

Article type: research paper

Keywords: $\quad$ SME; internationalisation; relationship; conflict; performance

JEL codes: $\quad$ F23, L14, L25

Received: 29 January $2018 \quad$ Revised: 29 March $2018 \quad$ Accepted: 7 May 2018

\section{Suggested citation:}

Ratajczak-Mrozek, M., Fonfara, K., \& Hauke-Lopes, A. (2018). The Impact of Conflicts in Foreign Business Relationships on SME Performance. Entrepreneurial Business and Economics Review, 6(2), 171183. https://doi.org/10.15678/EBER.2018.060209 


\section{INTRODUCTION}

Conflicts are an inherent feature of business relationships and can be defined as a tension between business or social entities. They can manifest themselves to different degrees and can range from day-to-day problems and small misunderstandings to severe escalating conflicts that threaten the existence of both the relationship and the company itself.

The impact of conflicts on companies' activities can be analysed from two perspectives. Firstly, one can focus on how conflicts affect the relationships themselves, including an impact on relationship development, trust, satisfaction and relationship termination (e.g. Lumineau et al., 2015; Vaaland, 2004). Secondly, the impact of conflict is perceived more broadly, taking into consideration its influence on the company's performance (e.g. Duarte \& Davies, 2003; Lam \& Chin, 2005). We see these two perspectives as interrelated because by affecting the relationship a conflict can influence performance as well.

International activities of companies entail higher risks of conflicts (Vaaland, Haugland, \& Purchase, 2004). However, in the existing literature conflicts in relationships with foreign entities have not been widely analysed (with the exception of Leonidou, Barnes, \& Talias, 2006; Vaaland et al., 2004). Especially, the existing research lacks the analysis of conflicts in SMEs foreign relationships, where due to the specific character of these enterprises, conflicts may have more severe negative consequences than for larger companies.

The objective of the article is to discuss the impact of conflicts in foreign business relationships on SME performance. In order to understand the nature of this impact, two possible ways in which conflicts influence the company's performance are considered: direct (conflicts $\rightarrow$ company's performance) and indirect (conflicts $\rightarrow$ business relationships $\rightarrow$ company's performance).

It has been assumed that:

- Conflicts in foreign business relationships have both a negative and positive impact on the SME performance (Proposition 1);

- SMEs may undertake actions to moderate outcomes of conflict in foreign business relationships and achieve a positive impact of conflicts on their performance (Proposition 2).

In the article we use the case study method and present the results of a qualitative study of 13 SMEs active in international markets. First, we present the theoretical background of the research problem, starting with the theory of conflicts in business relationships and a review of research on conflicts in international activity, SMEs and conflict outcomes. Next, we describe the research method and present the results of the study conducted among 13 SMEs. The first part of analysis focuses on the sources of conflict situations that appeared in the process of cooperation in foreign markets, in an attempt to explain why conflicts occur. In the second part the emphasis is placed on direct and indirect, positive and negative impacts of conflict in foreign business relationships on SME performance, in order to show how conflicts can influence SMEs. In the third part we propose a model of the positive impact of conflicts in foreign business relationships on SME performance. The analysis finishes with conclusions, including managerial implications. 


\section{LITERATURE REVIEW}

Social aspects are crucial in activities of every company, that is why conflicts are an inherent part of business relationships (Duarte \& Davies, 2003; Plank \& Newell, 2007). They can manifest themselves to different degrees and can range from day-to-day problems, misunderstandings to severe escalating conflicts that threaten the existence of the relationship and even the company itself. In the article we stay in line with the discussion and literature on the impact of conflict on performance (Duarte \& Davies, 2003; Lam \& Chin, 2005) and on constructive conflicts (Mele, 2011; Vaaland \& Håkansson, 2003).

Taking into consideration classifications presented in the literature (e.g. Duarte \& Davies, 2003; Plank \& Newell, 2007), the sources of conflicts can be divided into those that are strongly linked to the social aspects of cooperation (referred to in this article as relational) and conflicts that originate in company's operational day-to-day activities (referred to in this article as operational).

Conflicts can be both damaging and beneficial (Mele, 2011; Vaaland \& Håkansson, 2003). In terms of the negative impact of conflicts on relationships, research shows that conflict negatively impacts trust (Leonidou et al., 2006), loyalty (Plank \& Newell, 2007) and in extreme cases may lead to the relationship termination (Nordin, 2006). Conflicts also affect relationships positively. Vaaland and Håkansson (2003, p. 137) state that in a situation of severe conflict, when both partners are determined to collaborate, the value of the relationship in terms of mutual prosperity increases.

With respect to the impact of conflict in business relationships on companies' performance, research focuses on the general relationship between conflict and performance, without taking into consideration the international context of companies' activities or the specific characteristics of SMEs. In this regard research results are not unanimous. First, there is evidence of the negative impact of conflict in business relationships on performance (Lam \& Chin, 2005; Lin \& Germain, 1998). Second, there are studies showing that conflict in relationships can have a positive influence on performance (Finch et al., 2013). Regarding particular outcomes of conflicts in relationships, analyses focus on the impact of conflict on learning, innovation and development. Lam and Chin (2005) argue that conflicts in relationships result in distorted information flows, while Nordin (2006) maintains that conflicts can improve learning in alliance relationships. The positive impact of conflicts in relationships is particularly linked to creativity stimulation and innovation enhancement (Nordin, 2006; Vaaland \& Håkansson, 2003). It is even argued that a relationship without too many conflicts may become less innovative and slide back into stagnation (Duarte \& Davies, 2003, p. 92).

Taking into consideration potential cultural, economic and geographical differences, the risk of conflict in business relationships with foreign entities seems to be higher than in those with domestic ones (Skarmeas, 2006; Vaaland, 2004). Although the impact of conflicts is important in international business and relationships with foreign entities, this aspect has not been widely analysed in the literature. A large part of research in the field of conflict refers to their importance in general, without special emphasis on the specific character of conflicts in the international context.

What concerns existing and rather limited studies on conflicts in the international business relationships, research focuses on cultural sensitivity in the buyer-seller relation- 
ships (Skarmeas, 2006), the negative influence of task and emotional conflicts on performance and relationship quality (Rose \& Shoham, 2004) or tracks the evolution of conflicts in the international business network (Welch \& Wilkinson, 2005).

Analysis of conflicts with foreign entities is especially important with respect to small and medium-sized enterprises (SMEs). SMEs often lack economies of scale and resources needed to enter foreign markets (Deszczyński, Fonfara, \& Dymitrowski, 2017; Ellis, 2011). In order to conduct international activities, SMEs need to engage a bigger part of their general resources. In case of a failure this means a relatively greater negative impact, which is associated with a greater business risk for SMEs (Pangarkar, 2008). Given the above resource constraints and different specifics of internationalisation, conflicts in foreign business relationships can have a different and stronger impact on SMEs than on larger companies.

To the best of our knowledge research lacks complex analyses of conflict in business relationships of SMEs that operate in international markets. One study in this field investigated the impact of contractual conflicts experienced by SMEs on their further engagement in relationships (Ntayi, 2012). There is also a study of considerable cultural distance in interfirm conflict and its impact negative on relationship termination (Vaaland et al., 2004).

\section{MATERIAL AND METHODS}

The objective of the study was to identify the impact of conflicts in foreign business relationships on SME performance. In order to analyse this impact, a conceptual framework was proposed (Figure 1). Following the conceptual framework we have had to identify the negative and positive outcomes of conflicts and classify them. We also tried to identify sources of conflicts and moderators affecting positive impact of conflicts in foreign business relationships on SME performance.



Figure 1. The impact of conflicts in foreign business relationships on SME performance - conceptual framework Source: own elaboration.

The study was conducted using the case study method (Eisenhardt \& Graebner, 2007), as this kind of research is particularly suitable for understanding why and how things happen (Marschan-Piekkari \& Welch, 2004) and is believed to be the most appropriate in analyses of industrial networks and business relationships (Easton, 1998). However, one needs to be aware of the limitations of the case study method as it does not allow to conduct statistical verification or generalisations on the entire population.

The purposive sample of cases for the analysis was selected in order to reflect the phenomena of interest. As detailed criteria of SMEs selection we chose (1) company size 
(employment of less than 250 people in 2016), (2) company being not part (business unit) of a foreign multinational company, (3) company being active in foreign markets, (4) presence of conflicts or problem situations in company's foreign relationships. All 13 SMEs were based in Poland and were active in at least one foreign market, but represented different industries. The main characteristics of the companies are presented in Table 1 (in case of one SME we analysed relationships on two different foreign markets (T1 and T2), this is the reason why in the Table we present 14 cases).

Data were collected during interviews, which were held in the first half of 2016. To make sure the interviews yielded relevant information, a special guide for a semi-structured interview was developed. The interviews mainly consisted of open-ended and probing questions to encourage discussion of the phenomena. To ensure confirmability (Guba \& Lincoln, 1994), all interviews were recorded and later transcribed to provide interview protocols. Each interview lasted between 1 and 2 hours. The transcripts were used to prepare baseline compilations, which are the starting point for this article.

Table 1. The main characteristics of the analysed companies

\begin{tabular}{|c|c|c|c|c|c|}
\hline$\sum_{n}^{w}$ & Industry & Main foreign markets & $\begin{array}{c}\text { Year of } \\
\text { starting } \\
\text { foreign } \\
\text { expan- } \\
\text { sion }\end{array}$ & $\begin{array}{c}\text { Market } \\
\text { described } \\
\text { in the } \\
\text { case } \\
\text { study }\end{array}$ & $\begin{array}{l}\text { Year of start- } \\
\text { ing activity in } \\
\text { the foreign } \\
\text { market de- } \\
\text { scribed in the } \\
\text { case study }\end{array}$ \\
\hline$A$ & $\begin{array}{l}\text { Manufacturing operating room } \\
\text { equipment and furnishing }\end{array}$ & $\begin{array}{c}\text { European Union, Asia, } \\
\text { Africa }\end{array}$ & $\begin{array}{l}\text { late } \\
90 \mathrm{~s} .\end{array}$ & $\begin{array}{l}\text { Saudi } \\
\text { Arabia }\end{array}$ & 2011 \\
\hline$E$ & $\begin{array}{l}\text { Production of headgear for chil- } \\
\text { dren and teenagers }\end{array}$ & $\begin{array}{l}\text { Belarus, Russia, Ger- } \\
\text { many, Great Britain }\end{array}$ & 2000 & Belarus & 2011 \\
\hline $\mathrm{G}$ & Production of audio equipment & Germany, Norway & 2014 & Germany & 2016 \\
\hline $\mathrm{L}$ & $\begin{array}{l}\text { Production of agricultural ma- } \\
\text { chinery }\end{array}$ & Germany & 2013 & Germany & 2013 \\
\hline $\mathrm{M}$ & Software development & Western Europe & 2008 & $\begin{array}{l}\text { Great } \\
\text { Britain }\end{array}$ & 2010 \\
\hline $\mathrm{N}$ & $\begin{array}{l}\text { Production and distribution of } \\
\text { fittings for sanitary and heating } \\
\text { systems fittings }\end{array}$ & $\begin{array}{c}\text { Romania, Germany, } \\
\text { Czech Republic, Slovakia, } \\
\text { Lithuania, Latvia, Ukraine }\end{array}$ & 2006 & $\begin{array}{c}\text { Czech } \\
\text { Republic }\end{array}$ & 2010 \\
\hline 0 & Production of exhibition stalls & $\begin{array}{l}\text { Middle and Far East, } \\
\text { China, South Korea }\end{array}$ & 2007 & China & 2012 \\
\hline $\mathrm{P}$ & IT and new technologies & $\begin{array}{l}\text { born global, without } \\
\text { defined main foreign } \\
\text { markets }\end{array}$ & 2007 & USA & no data \\
\hline $\mathrm{R}$ & Specialist translations & Germany, Austria & 2004 & Germany & 2004 \\
\hline $\mathrm{S}$ & Software development & Baltic states & 2014 & Lithuania & 2014 \\
\hline $\mathrm{T} 1$ & $\begin{array}{l}\text { Production of lenses and } \\
\text { glasses frames }\end{array}$ & $\begin{array}{l}\text { Germany, Czech Repub- } \\
\text { lic, Slovakia, Lithuania }\end{array}$ & 2007 & $\begin{array}{c}\text { Czech } \\
\text { Republic }\end{array}$ & 2007 \\
\hline $\mathrm{T} 2$ & $\begin{array}{l}\text { Production of lenses and } \\
\text { glasses frames }\end{array}$ & $\begin{array}{l}\text { Germany, Czech Repub- } \\
\text { lic, Slovakia, Lithuania }\end{array}$ & 2007 & Germany & 2012 \\
\hline ZB & Services for car industry & Europe & 2012 & Germany & 2015 \\
\hline $\mathrm{ZC}$ & Logistics & France & 2006 & France & 2014 \\
\hline
\end{tabular}

Source: own study. 


\section{RESULTS AND DISCUSSION}

\section{Sources of Conflict Situations in Foreign Relationships of SMEs}

The interviewed managers reported conflict situations that originated in different aspects of business activities with foreign partners, which could be related to two identified types of sources of conflicts - relational and operational ones.

As far as identified relational conflicts are concerned, cultural differences as the source of conflict situations are mentioned in the case of relationships with greater psychic distance. These differences included language problems and different business attitudes. In one case the language barrier discouraged the business partner from further cooperation (L). Cultural differences were also manifested in different approaches to relationship building and cooperation development exhibited by Polish and French managers (ZC), as well as Polish and Chinese ones (O).

Another relational source of conflict in foreign business relationships was miscommunication ( $\mathrm{P}, \mathrm{ZB})$. This included miscommunication between individual people, such as managers representing different SMEs, as well as more general miscommunication at the company level. The latter form was related to mismatched expectations of cooperating partners. Excessive and imprecise customer expectations led to the dissatisfaction of one of the companies $(P)$ and even to the termination of the relationship.

The second type of the sources of conflict identified in the interviews was related to operational activities of the analysed SMEs. These included technical problems with goods and documents and the co-operator's desire to cut costs. In the case of four companies $(E, L, N, O)$, conflicts arose as a result of technical or quality requirements for delivered machinery $(L)$ or final products $(E, N)$ made by the foreign distributor. In one firm (ZC), severe conflicts were triggered by problems with imprecise conditions of cooperation. In one case the foreign partner's excessive willingness to cut costs led to a 6-month conflict (R). The conflict was especially severe as it also involved a big multinational enterprise that the firm in question was dependent on. Table 2 summarises identified relational sources and operational sources of conflict.

Table 2. Sources of conflict in foreign business relationships of SMEs

\begin{tabular}{|l|l|}
\multicolumn{1}{|c|}{ Relational sources } & \multicolumn{1}{c|}{ Operational sources } \\
\hline - Cultural differences & - Technical problems with product \\
- Disagreements with co-operators \& Miscommunication & $\begin{array}{l}\text { quality \& documentation } \\
\text { - Mismatched expectations }\end{array}$ \\
\hline
\end{tabular}

Source: own study.

\section{Indirect Impact of Conflicts in Foreign Relationships on SME Performance}

With respect to the impact of conflict on the relationship and its indirect impact on performance (see the conceptual framework), the first negative outcome is relationship termination. In three case studies, firms could not resolve the conflict and the relationship had to be terminated $(L, P, Z C)$. The immediate sources of termination included imprecise conditions of cooperation, mismatched expectations and cultural differences. As regards the conflict caused by cultural differences, one relationship (ZC) was negatively affected by the language barrier. 
A conflict in a foreign business relationship does not always have negative outcomes. In some cases $(\mathrm{O}, \mathrm{ZB}, \mathrm{ZC})$, conflicts with foreign partners contributed to strengthening the relationship. Partners came to know one another better, which improved mutual understanding, cooperation and increased mutual willingness to compromise. Knowledge gained from the conflict helped one firm $(L)$ to resolve conflicts with other business partners in foreign markets. Two managers (L, ZC) admitted that they were ready to incur extra costs (even if the conflict arouses owing to the foreign partner's fault) that decreased the company's income in order to maintain the foreign relationship. Such a situation can be classified as a negative indirect outcome of conflict. Two other managers added that the ability to make concessions showed commitment and adapting the partnership orientation had a positive effect on the relationship because it encouraged the business partner to seek a compromise (L, ZB).

\section{Direct Impact of Conflicts in Foreign Relationships on SME Performance}

Regarding the direct impact of conflict in foreign business relationship on performance, first of all, reported conflicts resulted in additional costs due to penalty fees for unfulfilled agreement (O). In another relationship that was more informal, personal, the same company was able to avoid paying penalty fees since the foreign partner was more lenient.

Some of the reported conflicts were resolved with positive outcomes. One example reported by a few companies ( $L, O, R, Z B, Z C$ ) was the continued cooperation. Another important positive outcome of conflicts mentioned in the interviews was the potential for fostering innovation. One manager described conflicts as conducive to creativity because they enabled the company to come up with innovative ways of conflict resolution, even though the business partners represented two different management styles (S).

Table 3 summarises identified conflict outcomes in foreign business relations of SMEs.

Table 3. The impact of conflicts on relationships and performance of SMEs in a foreign market

\begin{tabular}{|c|c|c|}
\hline $\begin{array}{l}\text { Type of } \\
\text { impact }\end{array}$ & $\begin{array}{c}\text { Impact on the relationship and indirect impact } \\
\text { on performance }\end{array}$ & $\begin{array}{l}\text { Direct impact } \\
\text { on performance }\end{array}$ \\
\hline $\begin{array}{c}\text { Negative } \\
\text { impact }\end{array}$ & $\begin{array}{l}\text { - Relationship termination } \\
\text { - Extra costs required to strengthen the relationship }\end{array}$ & $\begin{array}{l}\text { - Additional costs due } \\
\text { to contract fees }\end{array}$ \\
\hline $\begin{array}{l}\text { Positive } \\
\text { impact }\end{array}$ & $\begin{array}{l}\text { - Strengthening the relationship (facilitated by adapta- } \\
\text { tions, concessions) } \\
\text { - New knowledge derived from experience on how to } \\
\text { manage new foreign relationships }\end{array}$ & $\begin{array}{l}\text { - Continuity of orders } \\
\text { - Innovation }\end{array}$ \\
\hline
\end{tabular}

Source: own study.

\section{Discussion: A Model of the Positive Impact of Conflict in Foreign Business Relationships}

As it was exposed in our two propositions and the conceptual framework, our intention was to identify sources of conflict in business relationships and their direct and indirect impact on SME performance in foreign markets. The respondents perceived their company's performance first of all at the background of sales (export) and costs. That is why a negative impact of conflicts on a company performance was understood as an increase in costs and a decrease in exports (because of extra costs due to contract penalty fees, termination of relationships, etc.). The positive impact of conflicts on the SME's performance was related by respondents to the export growth due to innovations or continuity of orders. 
Our study confirmed findings made by Duarte and Davis (2003) that relational conflicts originate in miscommunication and misunderstandings. The results support also previous research made by Vaaland et al. (2004) or Sandström (1992), indicating that cultural differences are another important source of relational conflicts in foreign relationships. This is especially important because small companies in particular lack the necessary resources to employ foreign managers with adequate knowledge and experience of dealing properly with cultural differences (Ellis, 2011; Musteen, Francis, \& Datta, 2010). The analysis also revealed operational sources of conflicts. Such conflicts may be resolved by introducing additional quality control or required international certificates but for small companies with limited resources such solutions are not always possible. In the case of operational conflicts, problems were measurable and could easily be identified and managed. The conducted analysis shows comprehensive outcomes of conflicts in foreign business relationships for SMEs performance (Table 3). The identified outcomes are related to the impact of conflicts on the relationship and the direct impact on performance.

The negative impact on relationships and the resulting indirect negative impact on performance was manifested mainly in the termination of the relationship and extra costs incurred by SMEs in order to maintain the relationship. Such costs were justified in the case of SMEs which were ready to maintain their relationships in order to ensure the continuity of orders and secure future income. The direct negative impact included additional costs due to contract fees.

Like the negative impact, the positive impact of conflict on SME performance in international markets can also manifest itself in two ways. It is possible to identify indirect positive effects on performance, which improves because the relationship has been strengthened by the conflict thanks to a better understanding of mutual requirements. Our analysis confirms findings reported by Vaaland and Håkansson (2003) and Finch et al. (2013), suggesting that conflict can increase the value of a relationship. However, our case study analysis indicates that these were mainly SMEs that chose to bear the cost of saving the relationship, which often involved additional spending on operational activities.

We also observed a direct positive outcome of conflict on SMEs performance in foreign markets. In some cases, positively resolved conflicts not only enabled further cooperation but also fostered innovation in SMEs. Thanks to continuing foreign orders, the companies could improve their performance and develop their international activity. This is crucial for small companies, which do not have many resources and a sudden decline in the number of orders can threaten their very existence.

The realised study enabled to confirm the Proposition 1 concerning both negative and positive impact of conflicts on the SME performance. Our analysis strongly supports the importance of the financial outcomes of conflicts in foreign business relationships, which can be positive (like continuity of orders) and negative (additional costs for companies) and therefore affect SMEs performance in both ways. Financial aspects are mentioned in previous studies focused on the relation between conflict and performance (for example Duarte \& Davies, 2003; Finch et al., 2013), but the results of those studies are not as detailed and do not refer to specific outcomes, such as continuity of orders or their underlying mechanisms.

The conducted analysis enabled also to positively verify Proposition 2 regarding actions that SME may undertake to moderate outcomes of conflict in foreign business rela- 
tionships and achieve a positive impact of conflicts on their performance. Within the empirical study we have identified four moderators affecting the positive impact of these conflicts on SME performance: development of informal, personal relationships, trust, cultural awareness and formal actions. These moderators are included in the model of the positive impact of conflict in foreign business relationships on SME international performance (Figure 2). The model presents the complex nature of conflicts in foreign business relationships and links the conflict sources with their impact on SMEs performance and with four moderators enabling to achieve the positive conflict effects.

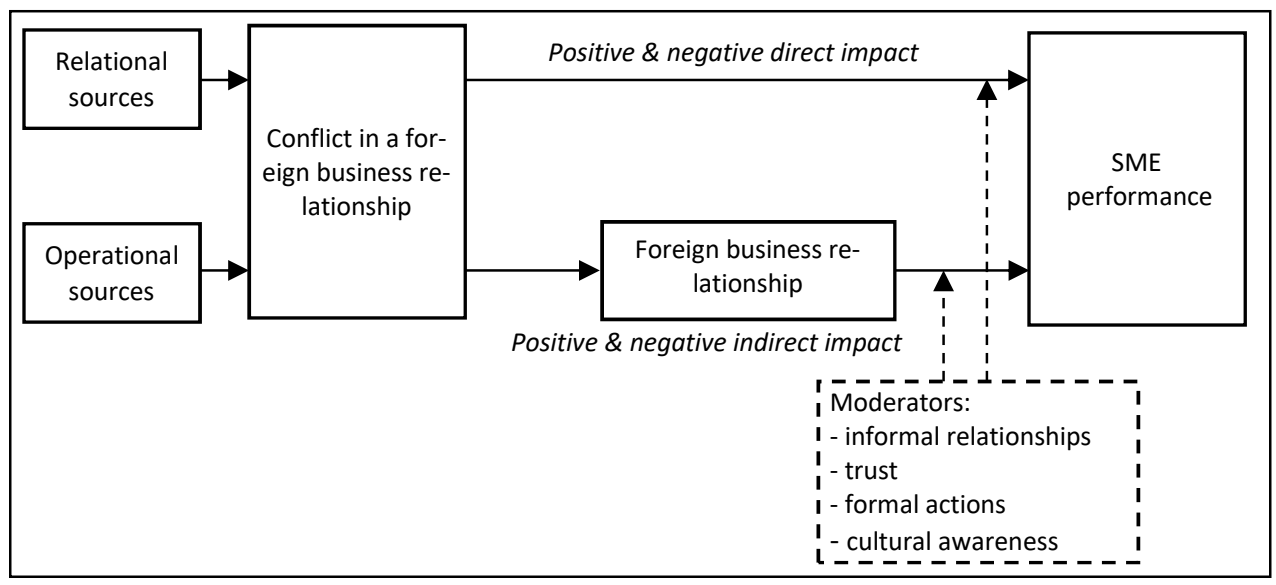

Figure 2. The model of the positive impact of conflict in foreign business relationships on SME international performance

Source: own elaboration.

Our study indicates that in an effort to prevent the negative impact of conflict, managers tried to develop informal, personal relationships. Such actions led to a higher level of mutual trust, tolerance for minor cases of non-compliance and awareness of mutual expectations. However, such an approach is not always possible when significant cultural differences are involved.

Many of the interviewed managers $(A, M, N, O, S, Z C)$ regarded trust as the crucial element that helped to overcome conflict and reinforce the relationships. The development of informal, personal relationships is seen as a moderator decreasing the negative impact of conflict in relationships on SME international performance. However, sometimes formal actions as a solution in conflict situations are needed. These actions included obtaining certificates, conducting a formal product quality examination or formal measures aimed at assuring proper comprehension of technical issues. Especially, in the case of operational conflicts, formal actions are sometimes a sufficient and at the same time the simplest solution that can prevent a possible negative impact on performance.

Our study has revealed that cultural awareness can positively moderate the impact of conflict on relationships. Because many SMEs have limited resources and their managers often have limited international experience, cultural awareness can play a key role in conflict resolution and in further cooperation with business partners. The investigated companies either adapted to the cultural background of their partners, or due to their 
cultural awareness, accepted the implications of cultural differences in the process of developing cooperation with their foreign partner.

\section{CONCLUSIONS}

The objective of our study was to discuss the impact of conflicts in foreign business relationships on SME performance. Additionally our intention was to find out how negative impacts could be transformed into positive ones. Due to the realised analysis, we positively confirmed Proposition 1 and Proposition 2.

The study contributes to research on conflicts in two ways. Firstly, it analyses the impact of conflict on SME performance in foreign markets. Given their limited resources, SMEs encounter more problems with foreign partners than bigger enterprises, which usually have more international experience and more resources to rely on in foreign operations. Our analysis provides a contribution to the existing and rather limited body of literature of SME international activity in conflict situations. Secondly, in our model we propose four moderators of a positive impact of conflict on SME performance in foreign markets. These moderators play an important role, especially for SME managers, who, despite limited resources of their companies and often their own limited international experience, can nevertheless control the moderators in order to derive positive outcomes from conflicts that appear in relationships with their foreign partners.

Several managerial implications can be drawn from the analysis. The four moderators set directions for actions required for successful conflict and relationship management. In this sense, our study confirms the conclusion drawn by Vaaland et al. (2004) that managers' awareness and attitude are of extreme importance while selecting and developing the relationship with new as well as existing partners. The positive impact of conflict in foreign business relationship may be obtained and the negative impact may be diminished by developing informal personal relationships with business partners. As our study has shown, foreign partners were ready to make concessions if informal relationships had previously been established. Trust is another important moderator that can have a positive impact on conflict resolution or can diminish the negative impact of conflict on performance. In our study we found that trust helped companies diminish the conflict and avoid negative outcomes. However, although trust is beneficial, an excessively high level of trust is associated with certain risks, like a false sense of security. The impact of conflict on performance can also be moderated by formal actions, including obtaining certificates, formal expertise or documents. The last moderator that needs to be mentioned is the level of cultural awareness exhibited by managers, which can help them anticipate potential sources of conflict. Since every relationship is unique, managers can exploit these moderators in different configurations in order to strengthen the relationship. Their effect should be treated as complementary, that is, e.g. the development of informal relationships does not exclude the possibility of taking formal action as well. The analysis has a practical value, especially when one considers that in some cases sources of conflict and its outcomes may not be limited to a specific dyadic relationship but might be transmitted from one dyad to another within the network. In effect, the conflict may have consequences for the entire network. That is why, another important implication is the fact that conflict analysis should be conducted from a broader perspective, in which 
conflict is viewed as a natural element of each relationship, and if handled properly can be beneficial for both sides of the relationship.

Our analysis is not free of some limitations which determine directions of further research. First of all, we analyse the conflict from the perspective of only one side of the business relationship. In the further research the analysis should involve two sides of the relationship. This approach would help to obtain more complex and objective analysis of SME conflicts in foreign business relationships. The second limitation is linked with the data on cultural differences that we were able to obtain from the interviews. In the future, more detailed research on how inexperienced SMEs (including ones operating in traditional and production branches) may operate in the markets with high psychic distance is recommended.

\section{REFERENCES}

Deszczyński, B., Fonfara, K., \& Dymitrowski, A. (2017). The Role of Relationships in Initiating the Internationalisation Process in B2B Markets. Entrepreneurial Business and Economics Review, 5(4), 91-109. https://doi.org/10.15678/EBER. 2017.050404

Duarte, M., \& Davies, G. (2003). Testing the conflict-performance assumption in business-to-business relationships. Industrial Marketing Management, 32(2), 91-99. https://doi.org/10.1016/S0019-8501(02)00223-7

Easton, G. (1998). Case Research as a Methodology for Industrial Network: A Realist Approach. In P. Naudé \& P.W. Turnbull (Eds.), Network Dynamics in Marketing (pp. 73-87). Oxford: Pergamon Press.

Eisenhardt, K.M., \& Graebner, M.E. (2007). Theory building from cases: Opportunities and challenges. Academy of Management Journal, 50(1), 25-32. https://doi.org/10. 2307/20159839

Ellis, P.D. (2011). Social ties and international entrepreneurship: Opportunities and constraints affecting firm internationalization. Journal of International Business Studies, 42(1), 99-127. https://doi.org/10.1057/jibs.2010.20

Finch, J., Zhang, S., \& Geiger, S. (2013). Managing in conflict: How actors distribute conflict in an industrial network. Industrial Marketing Management, 42(7), 1063-1073. https://doi.org/10.1016/j.indmarman.2013.07.024

Guba, E.G., \& Lincoln, Y.S. (1994). Competing paradigms in qualitative research. In Handbook of qualitative research (pp. 105-117). Thousand Oaks: Sage. Retrieved on May 26, 2018 from www.uncg.edu/hdf/facultystaff/Tudge/Guba\%20\&\%20Lincoln\%201994.pdf

Lam, P.K., \& Chin, K.S. (2005). Identifying and prioritizing critical success factors for conflict management in collaborative new product development. Industrial Marketing Management, 34(8), 761-772. https://doi.org/10.1016/j.indmarman.2004.12.006

Leonidou, L.C., Barnes, B.R., \& Talias, M.A. (2006). Exporter-importer relationship quality: The inhibiting role of uncertainty, distance, and conflict. Industrial Marketing Management, 35(5), 576588. https://doi.org/10.1016/j.indmarman.2005.06.012

Lin, X., \& Germain, R. (1998). Sustaining satisfactory joint venture relationships: The role of conflict resolution strategies. Journal of International Business Studies, 29(1), 179-196. https://doi.org /10.1057/palgrave.jibs.8490031

Lumineau, F., Eckerd, S., \& Handley, S. (2015). Inter-organizational conflicts. Journal of Strategic Contracting and Negotiation, 1(1), 42-64. https://doi.org/10.1177/2055563614568493 
Marschan-Piekkari, R., \& Welch, C. (2004). Qualitative Research Methods in International Business: The State of the Art. In R. Marschan-Piekkari \& C. Welch (Eds.), Handbook of Qualitative Research Methods for International Business (pp. 5-24). Northhampton: Edward Elgar.

Mele, C. (2011). Conflicts and value co-creation in project networks. Industrial Marketing Management, 40, 1377-1385. https://doi.org/10.1016/j.indmarman.2011.06.033

Musteen, M., Francis, J., \& Datta, D.K. (2010). The influence of international networks on internationalization speed and performance: A study of Czech SMEs. Journal of World Business, 45(3), 197-205. https://doi.org/10.1016/j.jwb.2009.12.003

Nordin, F. (2006). Identifying intraorganisational and interorganisational alliance conflicts - A longitudinal study of an alliance pilot project in the high technology industry. Industrial Marketing Management, 35(2), 116-127. https://doi.org/10.1016/j.indmarman.2004.12.010

Ntayi, J.M. (2012). Emotional outcomes of Ugandan SME buyer-supplier contractual conflicts. International Journal of Social Economics, 39(1/2), 125-141. https://doi. org/10.1108/03068291211188901

Pangarkar, N. (2008). Internationalization and performance of small- and medium-sized enterprises. Journal of World Business, 43(4), 475-485. https://doi.org/10.1016/j. jwb.2007.11.009

Plank, R.E., \& Newell, S.J. (2007). The effect of social conflict on relationship loyalty in business markets. Industrial Marketing Management, 36(1), 59-67. https://doi.org/ 10.1016/j.indmarman.2005.03.012

Rose, G.M., \& Shoham, A. (2004). Interorganizational task and emotional conflict with international channels of distribution. Journal of Business Research, 57(9), 942-950. https://doi.org/10.1016/S0148-2963(02)00490-3

Skarmeas, D. (2006). The role of functional conflict in international buyer-seller relationships: Implications for industrial exporters. Industrial Marketing Management, 35(5), 567-575. https://doi.org/10.1016/j.indmarman.2005.06.013

Vaaland, T.I. (2004). Improving project collaboration: Start with the conflicts. International Journal of Project Management, 22(6), 447-454. https://doi.org/10.1016/j.ijproman. 2003.11.003

Vaaland, T.I., \& Håkansson, H. (2003). Exploring interorganizational conflict in complex projects. Industrial Marketing Management, 32(2), 127-138. https://doi.org/10.1016/ S0019-8501(02)00227-4

Vaaland, T.I., Haugland, S.A., \& Purchase, S. (2004). Why Do Business Partners Divorce? The Role of Cultural Distance in Inter-Firm Conflict Behavior. Journal of Business-to-Business Marketing, 11(4), 1-21. https://doi.org/10.1300/J033v11n04_01

Welch, C., \& Wilkinson, I. (2005). Network perspectives on interfirm conflict: Reassessing a critical case in international business. Journal of Business Research, 58(2), 205-213. https://doi.org/10.1016/S0148-2963(02)00495-2 


\section{Authors}

The contribution share of authors is equal and amounted to $33 \%$ each of them.

\section{Milena Ratajczak-Mrozek}

Associate Professor at the Poznań University of Economics and Business, Poland. Her main areas of research include companies' relationships and networks in an international setting as well as their performance. She has published for "IMP Journal" and "Industrial Marketing Management", and is the author of the book titled "Network Embeddedness. Examining the Effect on Business Performance and Internationalisation" (Palgrave Macmillan 2017). She is a board member at the IMP Group.

Correspondence to: Milena Ratajczak-Mrozek, Ph.D., Poznań University of Economics and Business, Department of International Marketing, al. Niepodległości 10, 61-875, Poznań, Poland, email: milena.ratajczak@ue.poznan.pl

\section{Krzysztof Fonfara}

Full Professor, Head of the Department of International Marketing at the Poznań University of Economics and Business, Poland. His research interests span issues of the internationalisation process (network approach), market orientation, B2B marketing and relationship marketing. His has published in "International Marketing Review", "European Journal of Marketing", "International Journal of Research in Marketing", "Marketing Management" and "Industrial Marketing Management". He is an Editorial Committee member and reviewer at the "Industrial Marketing Management" journal, and a member of the EIBA and IMP Group.

Correspondence to: Professor Krzysztof Fonfara, Poznań University of Economics and Business, Department of International Marketing, al. Niepodległości 10, 61-875, Poznań, Poland, e-mail: krzysztof.fonfara@ue.poznan.pl

\section{Aleksandra Hauke-Lopes}

Associate Professor at the Poznań University of Economics and Business, Poland. In her research, she focuses on the strategic aspect of business networks, relationship management and knowledge transfer among companies in a culturally diversified international environment. She is a member of the EIBA and IMP Group.

Correspondence to: Aleksandra Hauke-Lopes, Ph.D., Poznań University of Economics and Business, Department of International Marketing, al. Niepodległości 10, 61-875, Poznań, Poland, email:a.hauke@ue.poznan.pl

\section{Acknowledgements and Financial Disclosure}

The paper was written thanks to the financial support from Poland's National Science Centre Decision no. DEC-2013/09/B/HS4/01145 ("The maturity of a company's internationalisation and its competitive advantage [network approach]", project leader: Professor Krzysztof Fonfara).

\section{Copyright and License}

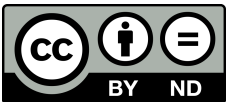

This article is published under the terms of the Creative Commons Attribution - NoDerivs (CC BY-ND 4.0) License http://creativecommons.org/licenses/by-nd/4.0/ 
